\title{
Tanulástámogató szolgáltatások a Savaria Egyetemi Központ Könyvtárában
}

A Nyugat-magyarországi Egyetem Savaria Egyetemi Központ Könyvtára (jogelőd: Berzsenyi Dániel Főiskola Könyvtára) 2008-tól támogatja a három, később két kar oktatási és tanulási, valamint kutatási tevékenységét. A kis létszámú könyvtár minőségi szakmai ellátásra törekvő munkáját 2007-ben az Év Könyvtára kitüntetéssel ismerték el, 2014-től pedig Minősitett Könyvtár címmel rendelkezik. E címek elnyeréséhez nagyban hozzájárult az a felismerés, hogy szükséges a könyvtári munka folyamatainak átértékelése, az oktatás paradigmaváltásának támogatása, s új irányok meghatározása. A felsőoktatási könyvtárakban ezek a változások a hallgatók módosuló tanulási szokásai miatt gyorsabban zajlanak.

A Savaria Egyetemi Központ Könyvtára (SEK Könyvtára) mint felsőoktatási szakkönyvtár elsősorban az oktatók és hallgatók számára nyújt szolgáltatásokat, de mint a Vas Megyei Pedagógia Intézet jogutód könyvtára a pedagógusok szakkönyvtári ellátását is biztosítja. A regionális szerepkörú könyvtári szolgáltatások mellett rendezvények szervezésével közmüvelődési funkciókat is ellát, amelynek fó célja a leendő hallgatók bevonzása az intézménybe.

Napi tapasztalataink megegyeznek a világ trendjeivel, amelyek szerint a hagyományos, könyvalapú tanulási folyamat digitális környezetbe helyeződik át, ahol a könyvtáraknak is meg kell találniuk a helyüket. A papíralapú, elsősorban könyvdokumentumok helyett az e-alapú tartalmak szolgáltatási környezetét kell kialakítani, alkalmazkodva az új igényekhez.

A felsőoktatás finanszírozási rendszerének kedvezőtlen változásai miatt a SEK Könyvtára törekszik a nyílt forráskódú, ingyenes, közvetlen pénzügyi ráfordítást nem igénylő szoftverek, alkalmazások megismerésére, és a szolgáltatási rendszerünkbe való beillesztésükre. A fejlesztések nagy részét belső és szükös humánerőforrás segítségével kell megvalósítanunk.

A tanulmány bemutatja a SEK Könyvtárában alkalmazott tanulást segító szolgáltatásokat, jó gyakorlatokat, amelyekkel a könyvtárosok a hagyományos könyvtári munka mellett aktívan részt vesznek a tanítási/tanulási folyamatok digitális alapú támogatásában. A használói igényeket figyelembe véve a könyvtárban alkalmazott legfontosabb eszközök, keretrendszerek, internetes szolgáltatások, portálok közül a következők emelendők ki:

1. Podcast videó csomagok

2. Videotorium.hu felsőoktatási videóportál

3. Moodle oktatási keretrendszer 
4. MAHARA e-portfólió keretrendszer

5. Turnitin/Ephorus plágiumkereső szolgáltatás

6. Drupal CMS tartalomkezelö rendszer

7. Digitális dokumentumtárak (NymE Tudástár, Intranet, Google szolgáltatások)

8. Magyar Tudományos Mủvek Tára (MTMT)

A könyvtár igyekszik ezeket az eszközöket funkcionálisan beépíteni a tanulást támogató szolgáltatási rendszerébe. ${ }^{1}$

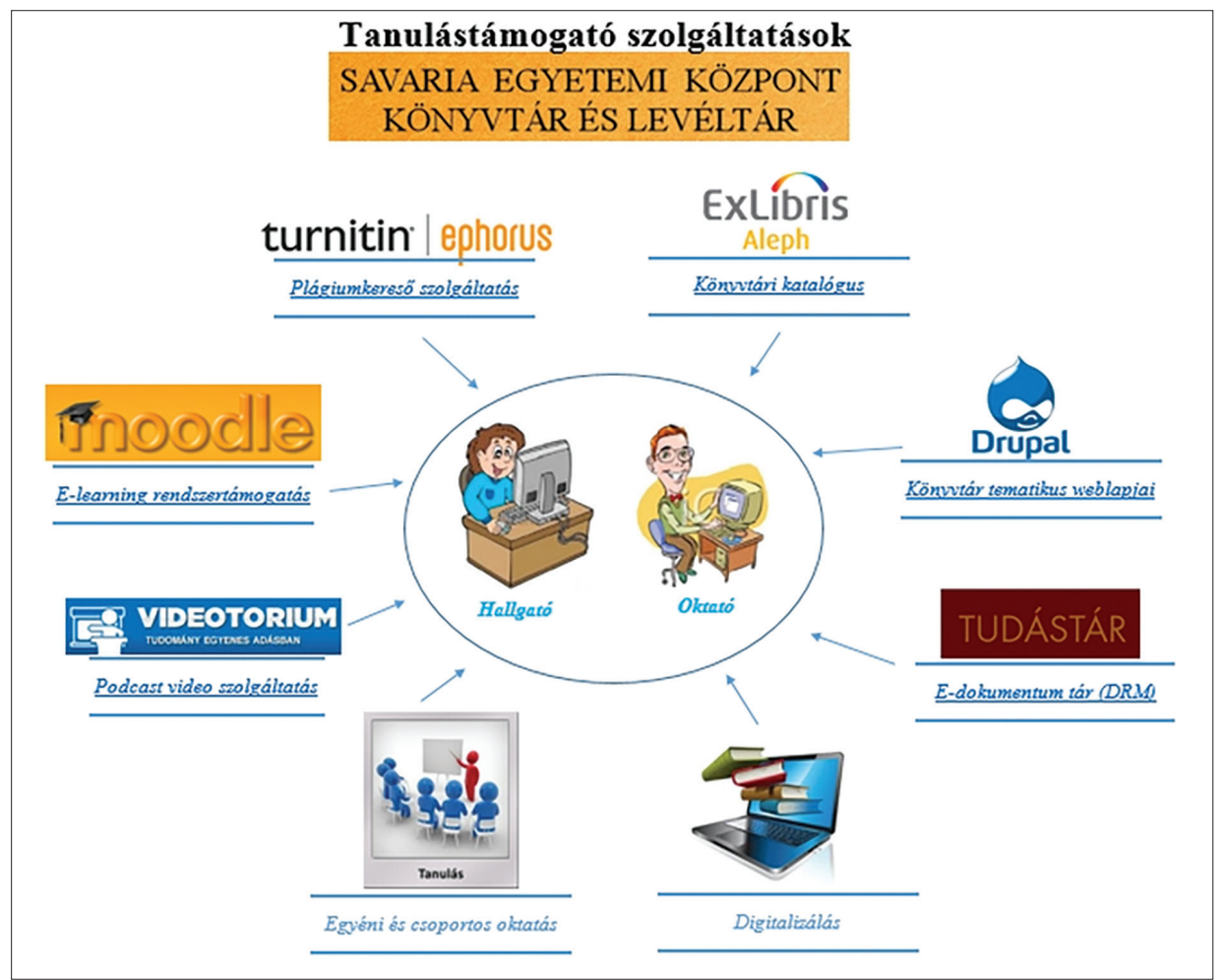

1. ábra. A SEK Könyvtára tanulástámogató szolgáltatási rendszere

\section{Podcast videó csomagok}

Az intézmény jogelődje, a Berzsenyi Dániel Főiskola jó hírnevet szerzett az oktatástechnikai eszközök alkalmazásában (,szombathelyi modell”). ${ }^{2}$ A tanárképzés egyik didaktikai alapeleme volt az 1980-as években a hallgatók tanítási

${ }^{1}$ http://tudastar.nyme.hu/sekkonyvtar/content/tanulastamogato-szolgaltatasi-rendszer (2016. augusztus 25.)

${ }^{2}$ Nyugat-magyarországi Egyetem Savaria Egyetemi Központ = A felsőfokú tanító- és óvóképzés első 50 éve. Szekszárd, Pécsi Tudományegyetem Illyés Gyula Főiskolai Kar, 2009. 131-142.p. 
gyakorlatainak videóra vétele és pedagógiai elemzése, s az akkori tanárok a mai napig is használható oktatófilmeket ${ }^{3}$ készítettek. A hallgatók diplomamunkájuk megírásához széleskörü gyakorlati, módszertani, technikai segítséget kaptak, például TV-stúdió, médiatár, oktatástechnikai csoport is müködött a föiskolán.

E hagyományok megőrzésébe kapcsolódott be a SEK Könyvtára, amikor a Médiatár állománya és szolgáltatásai integrálódtak a könyvtárba. Első lépésként a régi kazettákon örzött filmek digitalizálását kellett megoldani, amely során - nagyrészt önképzéssel - a könyvtárosok megtanulták a szoftveres videószerkesztés alapjait. Ezután szerény technikai keretek között elkezdődhetett a különböző rendezvények, előadások felvétele, szerkesztése és nyilvánossá tétele. Technikai fejlődést hozott az egyetem podcast pályázata, amelynek keretében a karok 1-1 videócsomagot - kamera, állvány, hangtechnika, szerkesztőgép, táska, szoftverek - kaptak a felvételek elkészítéséhez. A szombathelyi három kar podcast csomagjait a SEK Könyvtára fogadta be, vállalva azok kölcsönzését, a technikai támogatást, a felvételek elkészítésének szervezését, illetve az anyag szerkesztését és megosztását. 2010-től sikerült bevezetni új szolgáltatásként a folyamatot, s mostanra már több mint 900 videófelvétel érhető el a felsőoktatás videóportálján a Videotorium adatbázisban. A feltöltött és megosztott felvételek több mint 90\%-a nyilvánosan elérhető. ${ }^{4}$

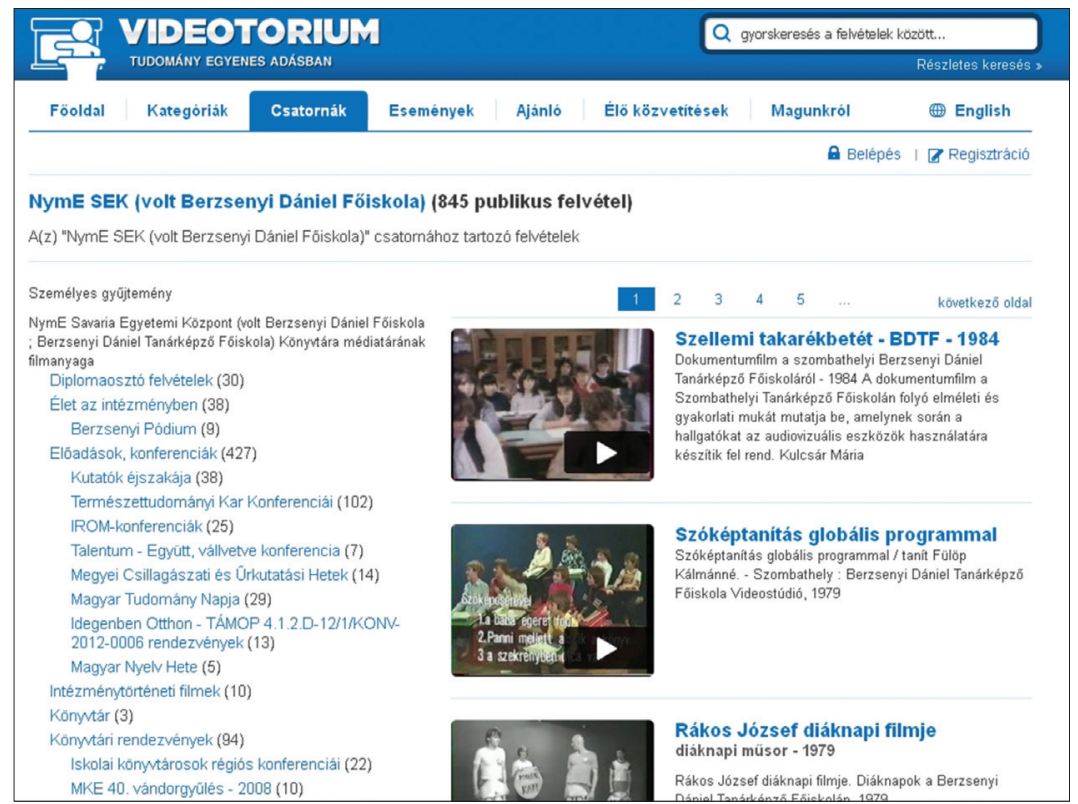

2. ábra. A SEK Könyvtára csatornája a Videotorium.hu portálon

\footnotetext{
${ }^{3} \mathrm{http} / / /$ videotorium.hu/hu/channels/292/oktatofilmek (2016. augusztus 25.)

${ }^{4} \mathrm{http} / / /$ videotorium.hu/hu/channels/273 (2016. augusztus 25.)
} 
A nyugati modell alapján kialakított podcast lényege, hogy az oktatók felveszik saját előadásaikat, és azt valamilyen hozzáférési joggal visszaosztják a hallgatóiknak. Az oktatók terheinek csökkentése, valamint a minőségi oktatás elősegítése érdekében a folyamat nagy részét a könyvtár átvállalja, így az oktatóknak csak a tartalomra kell koncentrálniuk.

Mintaprojektként a Gimnasztika tantárgy teljes előadásanyaga és gyakorlati óráinak videófelvételei készültek el. Az oktató igényei alapján többkamerás rögzítés történt, majd a PinnacleStudio szoftver idősávjain szerkesztettük meg a végső változatot. Az oktató végignézte, bejelölte a vágási pontokat, amely alapján már egyszerủ volt a végső anyagot összeállítani. Hosszabb távon a gyakorlatban pedig sikerült kialakítani azt a munkarendet, amely alapján a lehető legkevesebb munkaidő ráfordítással elkészíthető az óra végleges felvétele.

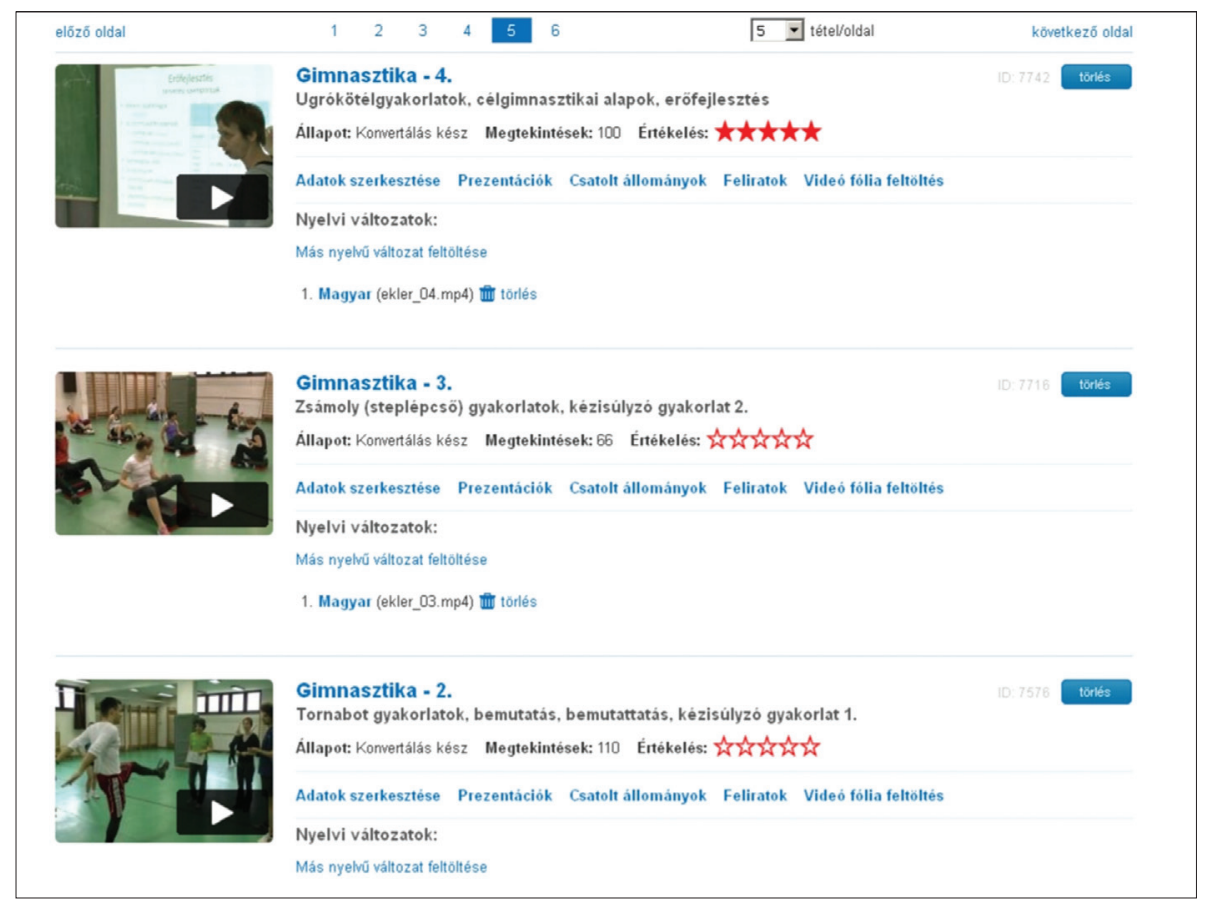

3. ábra. Gimnasztika órafelvételek a Videotorium.hu portálon

Az oktató a Google kérdőív szerkesztő szolgáltatása segítségével részletes felmérést készített a videós projekt oktatásra gyakorolt hatásáról. A visszajelzések alapján elmondható, hogy a hallgatók pozitívan értékelték a későbbi visszanézés lehetőségét, az értékeléseknél pedig jobb eredményeket értek el, mint az előző évfolyamok.

Az órai felvételek mellett a legtöbb film a különböző rendezvényekhez, konferenciákhoz, előadás-sorozatokhoz kapcsolódóan készült el. Az eddigi tapasz- 
talatok szerint - a jelenleg rendelkezésre álló technikai feltételek mellett - a felvétel idejének átlagban a háromszorosa az az időtartam, amely alatt a videó az interneten hozzáférhetővé válik.

\section{Videotorium.hu, a felsőoktatási videóportál}

A podcast szolgáltatás második alappillére az anyagok Videotorium-ban ${ }^{5}$ való közzététele. E videómegosztó legnagyobb erénye a sokrétű metaadatleírási és visszakeresési lehetőség mellett a segédanyagok, feltöltött prezentációk felvételhez füzhetősége. A diák a lejátszás során valós időben megjelennek a videó mellett, így nem kell törekedni a profi kamerás felvételekre. Utólag jó minőségben lehet mellékelni bármilyen segédanyagot, amely a megértést könnyíti, és nem a videószerkesztésben kell sok munkával elhelyezni a felvételen. A hatékony visszakeresést támogatva a Videotorium keresőmotorja a feltöltött prezentáció szövegében is keres.

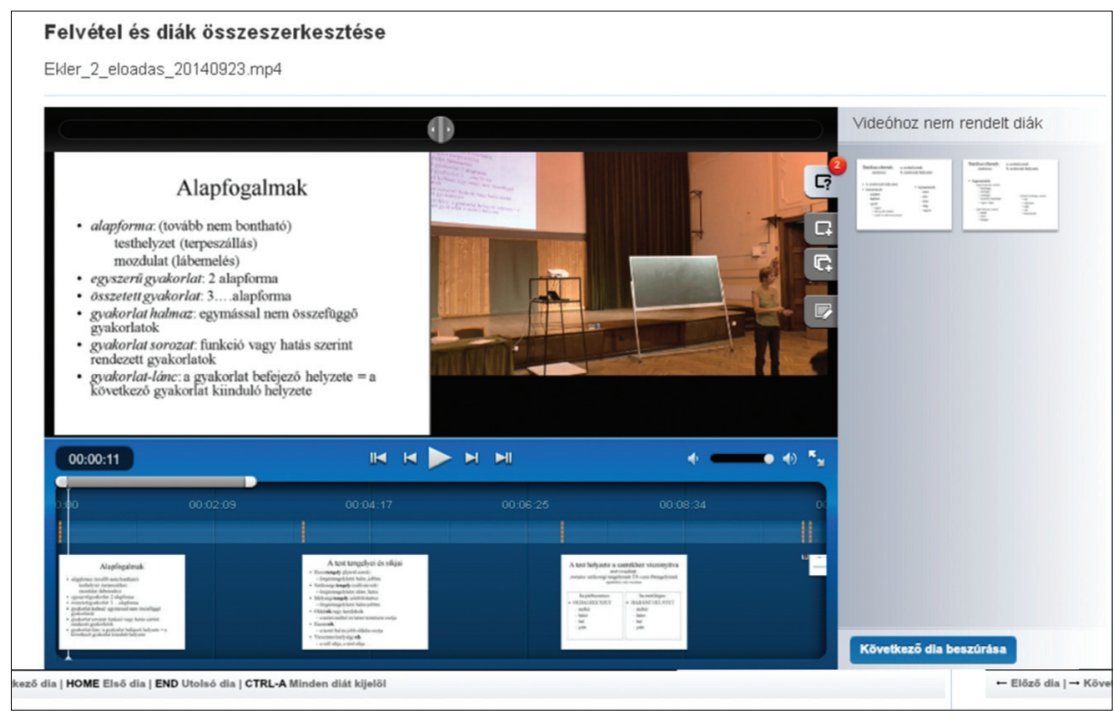

4. ábra. Prezentáció hozzárendelése a Videotorium.hu portálon

Az e-tananyagok készítéséhez is ezt a technikai megoldást ajánlják a könyvtár munkatársai. A Videotorium szolgáltatási rendszerében lehetőség van szöveges állományok feltöltésével (például srt, sub) feliratok elhelyezésére, prezentáció helyett a számítógép képernyőjén rögzített videó mellékelésére, valamint többnyelvű felvételek feltöltésére, párhuzamos kezelésére, kiegészítő dokumentációk megosztására. Az oktatók által készített előadások hozzáférési jogai is jól szabályozhatók a rendszerben (EduID, IP-cím, csoportok, időalapú beállítás

${ }^{5} \mathrm{http}: / /$ videotorium.hu (2016. augusztus 25.) 
stb.), például a már említett gimnasztika előadások megtekintését csak a levelező képzésben résztvevő hallgatók számára engedélyezte az oktató.

A könyvtárban két könyvtáros foglalkozik a podcast szolgáltatás müködtetésével, a felvételek szerkesztésével, megosztásával. Időszakosan sikerül bevonni hallgatókat, közösségi szolgálatban résztvevő tanulókat is egyes részfeladatok elvégzésébe, elsősorban a felvételek készítésébe és a prezentációk hozzáfüzésébe.

A Videotorium-ba feltöltött több mint 900 felvétel nézettségi statisztikája azt mutatja, hogy a hallgatók szívesen használják és látogatják e felületet: a 2015. évi statisztika már 50 ezer feletti kattintási értéket mutatott. A tanulási szokások változását jól érzékelteti, hogy a sport témájú oktatófilmek, előadások a teljes nézettség 50 százalékát teszik ki. Az úszással, tornával, sportpedagógiával stb. foglalkozó oktatófilmek ( $56 \mathrm{db}$ ) folyamatosan a Videotorium nézettségi toplistái élén járnak.

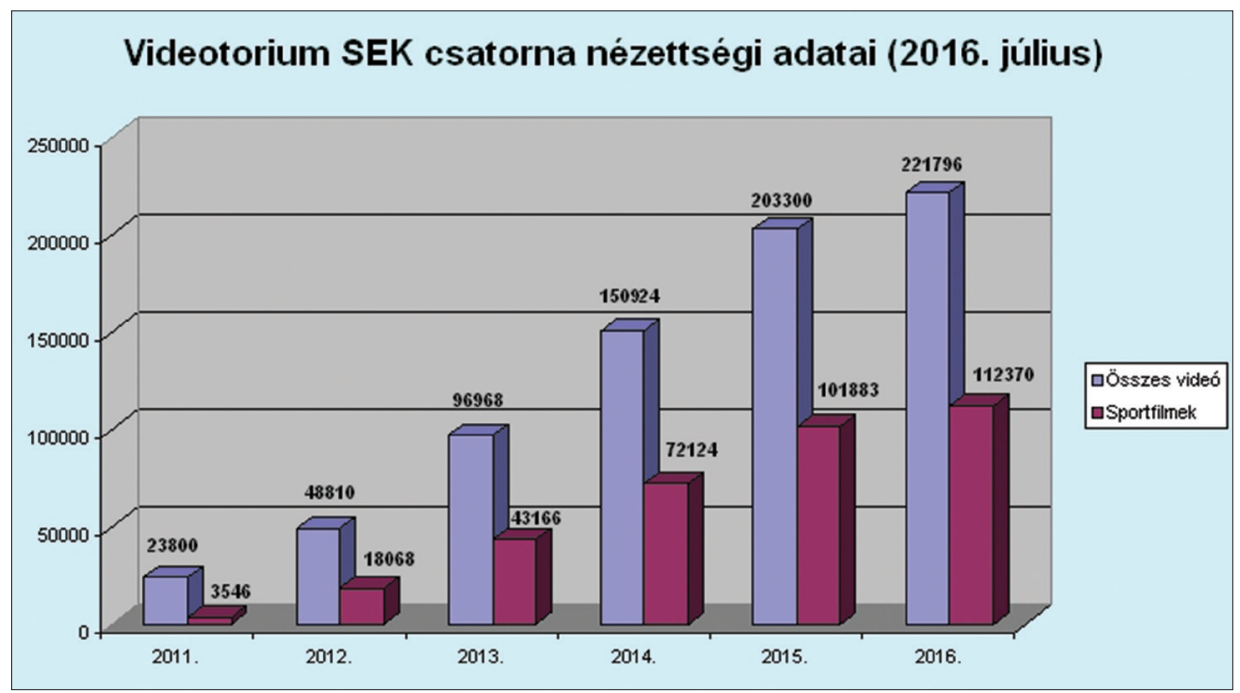

5. ábra. SEK Könyvtára felvételeinek nézettségi adatai a Videotorium.hu portálon

\section{Moodle oktatási keretrendszer}

A SEK Könyvtárának 5 munkatársa vett részt elektronikus tananyagkészítéssel kapcsolatos továbbképzéseken, amelyeknek egyik alapeleme a Moodle-learning ${ }^{6}$ keretrendszer elsajátítása volt. A megszerzett ismeretek segítségével a könyvtárosok a szombathelyi pedagógusképzés támogatására létrehozott Moodle felületen a rendszeradminisztrációs tevékenység mellett egyénre szabott módszertani oktatást is nyújtanak az oktatók részére. A Moodle-kurzusok kialakítása során konkrét javaslatokkal segítik a könyvtári szolgáltatások (DRM, plágiumkeresés, Videotorium, digitalizálás stb.) integrálását, támogatva a tanítási/tanulási folyamatot.

\footnotetext{
${ }^{6} \mathrm{http}: / /$ nyo.pszk.nyme.hu (2016. augusztus 25.)
} 
Az alkalmazás ismét egy Gimnasztika kurzushoz kapcsolódó példával illusztrálható. A testnevelés szakos hallgatók rajzírás tanulásának elősegítése érdekében digitalizálásra került az összes rajzírásforma, majd ezek felhasználásával kérdésbank és gyakorló tesztek készültek. A hallgatók a gyakorló tesztek segítségével memorizálhatták a rajzokhoz tartozó fogalmakat.

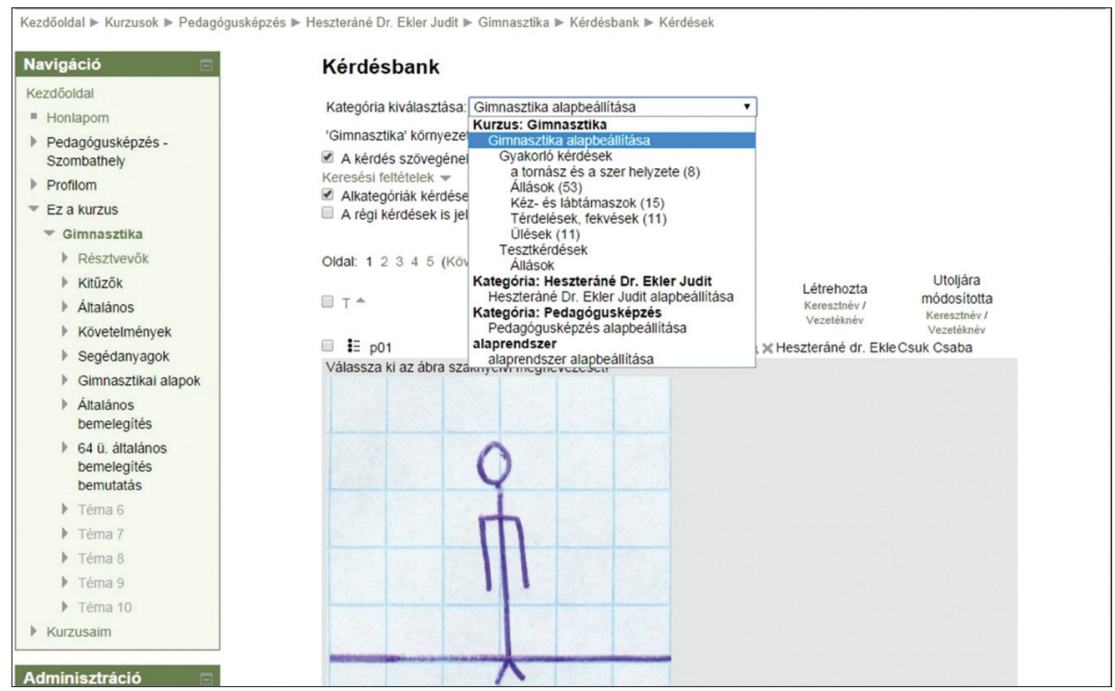

6. ábra. Kérdésbank a Savaria Egyetemi Központ Moodle portálján

\begin{tabular}{|c|c|c|c|}
\hline \multicolumn{4}{|l|}{ Gimnasztika } \\
\hline \multicolumn{4}{|c|}{ A(z) 2014. jünius 30., héttö, $06: 54$ óta gyūjtôtt naplókból kiszámitva. } \\
\hline Tevékenység & Nézetek & Kapcsolódó blogüzenetek & Utolsó belépés \\
\hline Eä́ltalànos nirfórum & 145 & - & 2014. oktober 8. szerda, 19.53 ( 4 b́ra 10 perc) \\
\hline 䂇 Az ezerarcú gimnasztika & 21 & . & 2014. szeptember 29, hétro, $12: 00$ (9 nap 12 óra) \\
\hline \multicolumn{4}{|c|}{ Követelmények } \\
\hline Enappali tagozat & 168 & - & 2014. oktiober 8. szerda. $11: 47$ (12 óra 17 perc) \\
\hline Levelezö tagozat & 95 & - & 2014. oktober 8, azerda, $17: 17$ ( 6 ora 46 perc) \\
\hline Részképzés & 47 & - & 2014. oktober 8, szerda. $20: 11$ ( 3 ora 52 perc) \\
\hline \multicolumn{4}{|c|}{ Segédanyagok } \\
\hline Segédanyagok & 253 & - & 2014. oktober 8, szerda, $21: 52$ (2 ora 12 perc) \\
\hline - 96 ütemũ gyakorlat bemutatója - vidé & 94 & - & 2014. oktober 8, szerda, $21: 38$ (2 bra 25 perc) \\
\hline$\checkmark$ Gyakorió teszlek a rajzirás tanulásához - állások & 2133 & - & 2014. oktober 8 , szerda, $21: 38$ (2 ora 26 perc) \\
\hline$\checkmark$ Gyakorló teszlek a rajzirás tanulásához - ülések & 961 & - & 2014. oktober 8 , szerda, 21,36 (2 bra 27 perc) \\
\hline$\nabla$ Gyakorio teszlek a rajzirás tanulásánoz - kèz- és lábtámaszok & 984 & - & 2014. oktober 8 . szerda, 21.46 ( 2 ora 18 perc) \\
\hline$\checkmark$ Gyakorló teszlek a rajzirás tanulásához - térdelések és fekvések & 795 & - & 2014. oktober 8, szerda, $21: 33$ (2 bra 30 perc) \\
\hline$\checkmark$ Gyakorlo teszlek a rajziras tanulásánoz - a tornász és a szer nelyzete & 1169 & - & 2014. oktober 8, szerda, 21.53 (2 óra 10 perc) \\
\hline Gimnasztika elōadások levelezósōknek & 7 & - & 2014. oktober 8, szerda, $21: 19$ (2 ora 44 perc) \\
\hline \multicolumn{4}{|c|}{ Gimnasztikai alapok } \\
\hline B. Gimnasztikai alapok & 187 & . & 2014. oktober 8 , szerda, 20.21 ( 3 óra 43 perc) \\
\hline
\end{tabular}

7. ábra. Gimnasztika gyakorló tesztek nézettségi adatai a Savaria Egyetemi Központ Moodle portálján 
A kurzus zárótesztjében már a hallgatóknak kellett beírni a megfelelö fogalmakat. A Moodle statisztikája szerint a hallgatók a gyakorló teszteket tömeges méretekben kezdték el használni, jobbak lettek az eredményeik, és az oktatónak sikerült elérni, hogy a tanulók már év közben is foglalkozzanak a tananyaggal.

A könyvtár módszertani támogatásának fő eleme, hogy az oktatók megtalálhassák oktatási folyamatuk azon pontjait, amelyeket hatékonyabbá tudnak tenni a Moodle rendszer használatával.

\section{MAHARA e-portfólió rendszer}

A Moodle rendszerrel párhuzamosan bevezetés alatt áll a MAHARA ${ }^{7}$ e-portfólió szolgáltatás is. A keretrendszer felhasználói közvetlenül a Moodle felületéről tudják átküldeni az elkészített e-dokumentumaikat a MAHARA-ba, és ott saját oldalon gyüjthetik össze, mutathatják be a munkásságukat (e-portfóliójukat), segítve például a későbbi elhelyezkedésüket. Cél továbbá a pedagógusképzés során keletkező portfoliók e-alapú formájának kialakítása, amely részét képezheti a tanulmányi követelményrendszernek is.

\section{Turnitin/Ephorus plágiumkereső szolgáltatás}

A SEK Könyvtára a minőségi oktatást segítendő szolgáltatásként az Ephorus ${ }^{8}$ plágiumkereső rendszert vezette be a TÁMOP-3.2.4.A-11/1-2012-0060 „,Tudásdepó-Expressz" pályázat keretében. A karokon fogalmazódott meg az igény, hogy az intézményben keletkező e-dokumentumok (elsősorban a diplomadolgozatok) plágiumellenőrzése megvalósuljon. Az Ephorus cég vállalta a 2003 óta már digitálisan őrzött szakdolgozatok betöltését, így már az indulásnál több mint 10000 diplomadolgozat szerepelt keresési alapként. Ezenkívül a rendszer több mint 1 millió weblap tartalmával is összehasonlítja a dokumentumokat, megkímélve az oktatót a keresgéléstől. A rendszer müködését a 8. ábra szemlélteti.

A folyamat lényege:

1. Meghívó alapján az oktató regisztrál és létrehozza a dokumentum feltöltéséhez szükséges kódot a plágiumkereső webes felületén. ${ }^{9}$

2. A hallgató a feltöltő ürlapon ${ }^{10}$ keresztül az oktató által megadott adatok (kód) segítségével feltölti a szöveges dolgozatát.

3. A plágiumkereső végrehajtja az összehasonlítást, és a jelentést e-mailben elküldi az oktatónak.

\footnotetext{
${ }^{7}$ http://eportfolio.nyme.hu (2016. augusztus 25.)

${ }^{8} \mathrm{https}: / /$ www.ephorus.com (2016. augusztus 25.)

${ }^{9} \mathrm{https}: / /$ www1.ephorus.com (2016. augusztus 25.)

${ }^{10} \mathrm{http}: / /$ sek.nyme.hu/konyvtar/plagium (2016. augusztus 25.)
} 


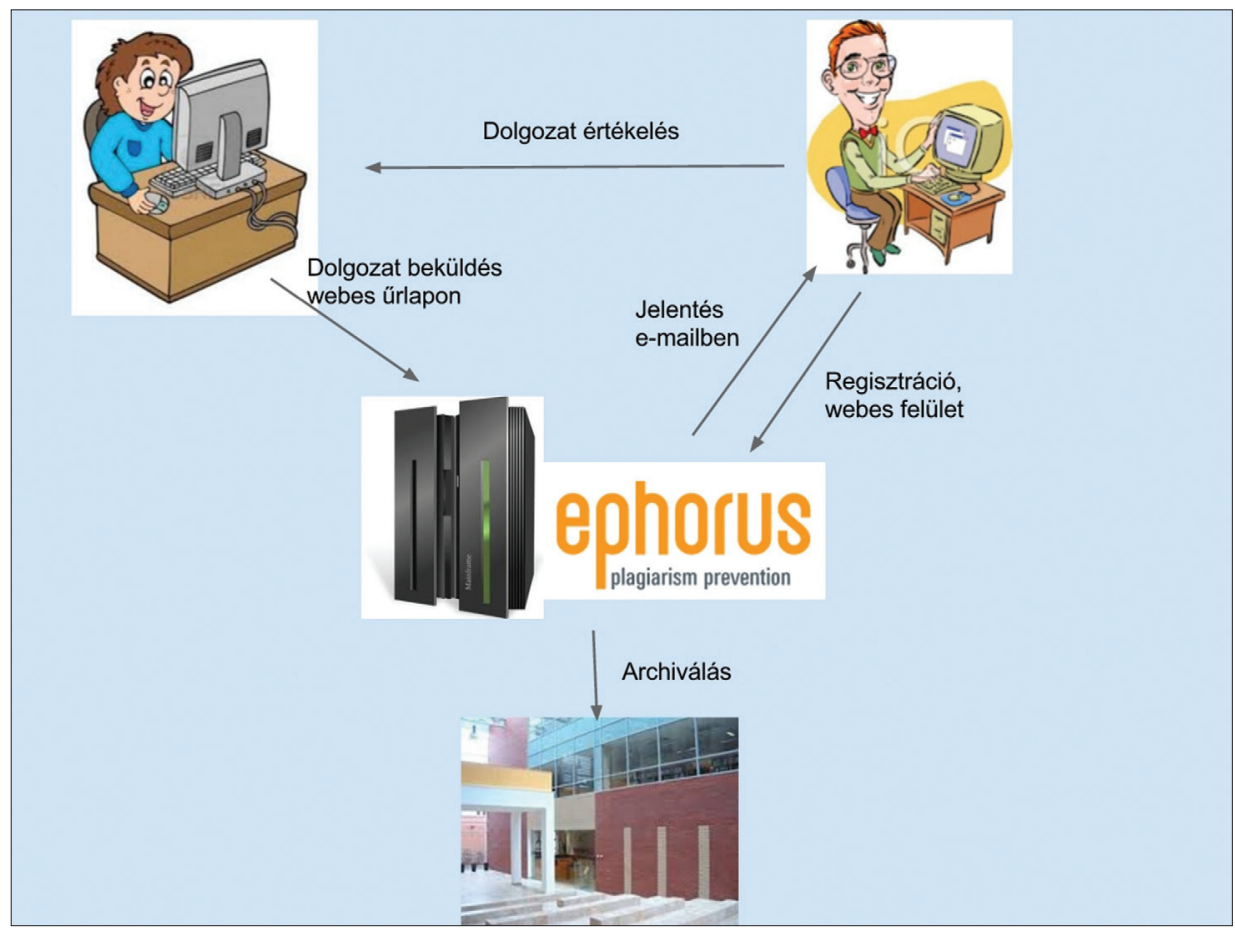

8. ábra. Plágiumkereső szolgáltatás folyamata a Savaria Egyetemi Központ Könyvtárában

A megőrzés biztosítása érdekében, valamint az oktatók munkájának segítése céljából a könyvtár az első pontban szereplő ürlapot kiegészítette két funkcióval. A feltöltés során a dokumentum elmentésre kerül a helyi könyvtári szerverre, ugyanakkor az oktató e-mailes értesítést kap a feltöltésről, amely tartalmazza az eredeti dokumentumhoz vezető letöltési linket is, így nem kell belépnie a plágiumkeresőbe. Végeredményben az oktatónak egy egyszeri regisztráció és kódbeállítás után már csak az e-mailben megkapott plágiumkeresési jelentést kell értékelnie. A jelentés szemléletesen, az egyes találati helyeket külön kezelve, könnyen értelmezhetö formában mutatja meg a szövegegyezéseket. Nyugati gyakorlat alapján a szolgáltatás elsődleges célja a hallgatók szerzői jogoknak megfelelő idézési kultúrájának fejlesztése. 


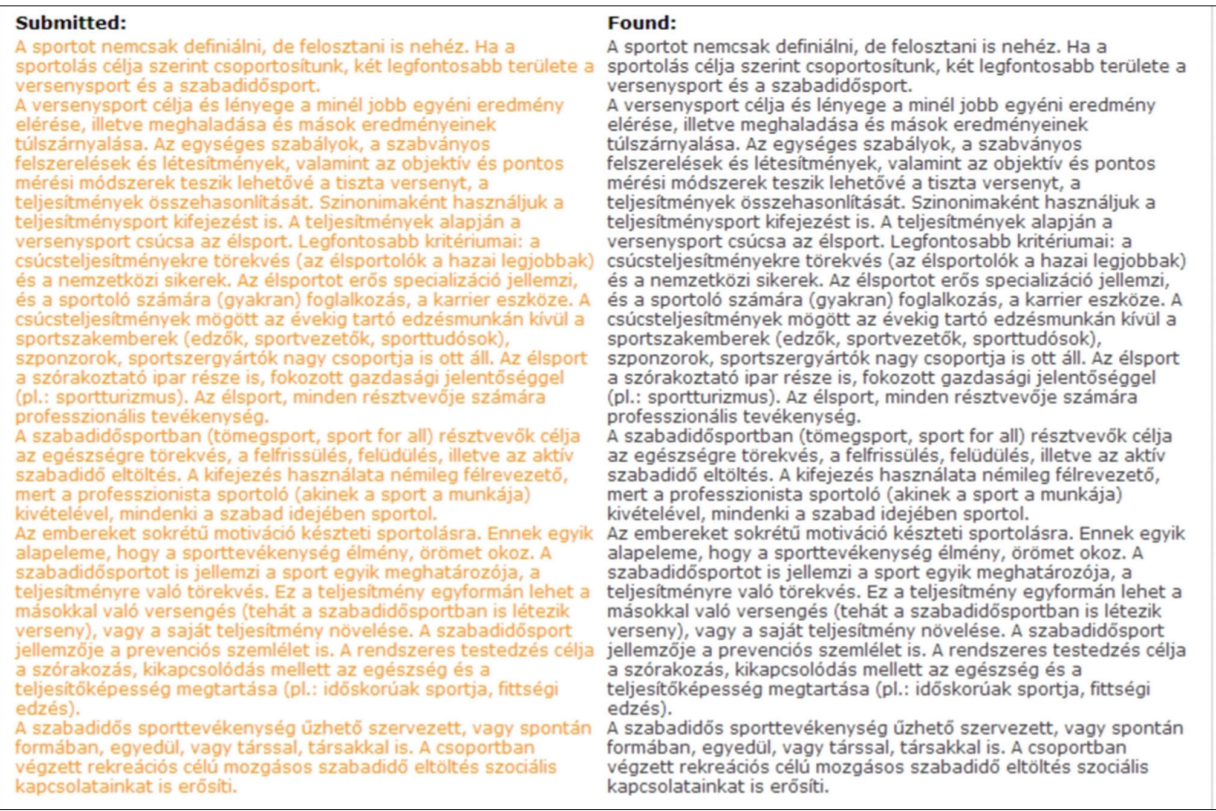

9. ábra. Turnitin/Ephorus plágiumkereső szolgáltatás plágiumjelentése

\section{Drupal (CMS) tartalomkezeló rendszer}

A SEK Könyvtára 2011-ben könyvtárosi adminisztrátor fejlesztésével kezdte el használni a Drupal ${ }^{11}$ keretrendszert, míg előtte Wordpress és Joomla tartalomkezelők láttak el célirányos funkciókat. A különböző igényeknek megfelelő szoftver az alábbi kritériumok alapján került kiválasztásra:

a) többfelhasználos tartalomkezelő, ahol bármely kolléga, felhasználó tartalmat állíthat elő a jogosultsági szintjének megfelelően;

b) Vezetői Információs Rendszer (VIR) kialakítása: könyvtárosok információközvetítő helye, ahol mindenki ugyanazt a könnyen visszakereshető tartalmat látja, kommunikálhat a rendszer segítségével, illetve bárhonnan elérheti;

c) különböző dizájn lehetőségével egyszerüen hozható létre új weblap az igényeknek megfelelöen;

d) saját webes adatbázisok hozhatók létre programozói tudás nélkül;

e) többnyelvüség támogatása.

Elsőként a könyvtár új honlapja ${ }^{12}$ készült el Drupal segítségével, amelybe áttöltésre került a korábban Wordpressben müködő könyvtári Vezetői Információs Rendszer.

${ }^{11} \mathrm{http}: / /$ www.drupal.hu (2016. augusztus 25.)

12 http://tudastar.nyme.hu/sekkonyvtar (2016. augusztus 25.) 
Elkészült egy Média adatbázis, ${ }^{13}$ ahol az intézménnyel kapcsolatos sajtófigyelések adatai kerülnek rögzítésre, kiegészülve az eredeti híradás teljes szövegủ másolatával, és/vagy digitalizált (pdf) változatával. A szerkezet kialakításánál fontos elv volt, hogy az egyes képzési területek (például kar, intézet, sport) önállóan is leválogathatók legyenek, így egyszerüen felhasználhatják a szakok akkreditációjában vagy a pályázati elszámolásoknál is.

A Magyar Nyelvi Tanszék által gyüjtött, felbecsülhetetlen értékủ Élő nyelvi hanganyag gyüjtemény webes felületén ${ }^{14}$ a magnókazettákról digitalizálandó hangfelvételek válnak közkinccsé.

A Savaria Egyetemi Központ Könyvtára honlapján kívül jelenleg 8 féle különböző honlap ${ }^{15}$ üzemel ugyanazon Drupal motoron keresztül. Például az Ünnepi Könyvheti Felolvashow - SZombathely az Olvasás Fövárosa Is (SZOFI) ${ }^{16}$ rendezvénysorozatunk már 5 éve népszerüsíti az olvasás mellett intézményünket is.

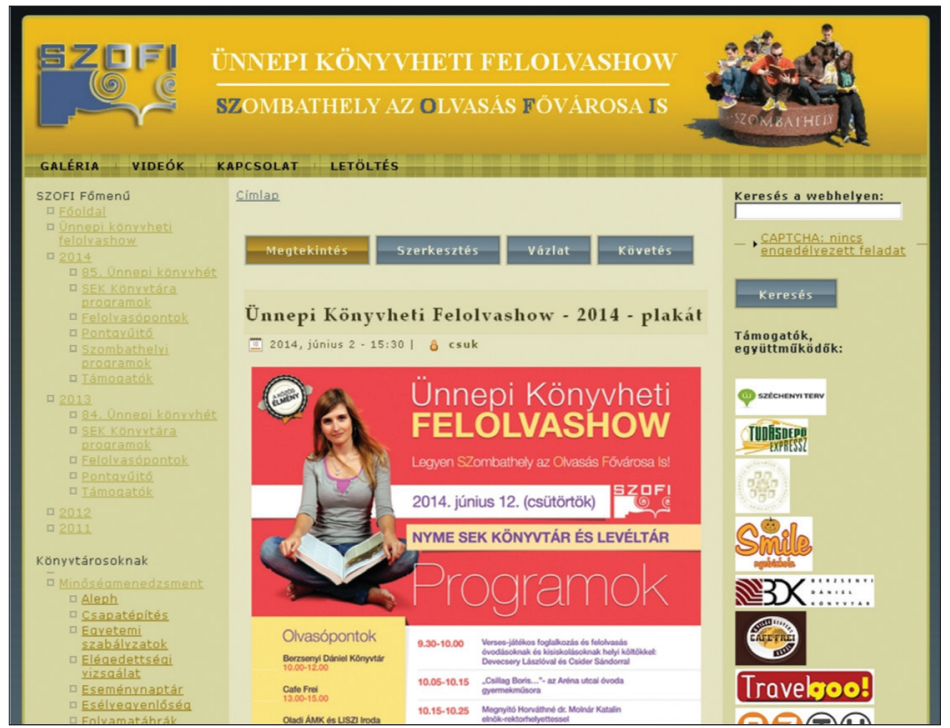

10. ábra. Drupal alapú weblap a Savaria Egyetemi Központ Könyvtárában

A szombathelyi felsőoktatás története ${ }^{17}$ címü honlap kívánja összegyüjteni az intézmény történetével kapcsolatos információkat és dokumentumokat, amelyek a könyvtár irányításával digitalizálásra kerülnek.

${ }^{13} \mathrm{http}: / /$ tudastar.nyme.hu/sekkonyvtar/sajto/teljes (2016. augusztus 25.)

${ }^{14} \mathrm{http}: / /$ tudastar.nyme.hu/sekkonyvtar/elonyelv (2016. augusztus 25.)

$15 \mathrm{http} / / /$ tudastar.nyme.hu/sekkonyvtar/content/sek-koenyvtara-tematikus-weblapjai (2016. augusztus 25.)

${ }^{16} \mathrm{http} / / /$ tudastar.nyme.hu/sekkonyvtar/szofi (2014. június 30.)

${ }^{17} \mathrm{http}: / /$ tudastar.nyme.hu/sekkonyvtar/intezmenytortenet (2016. augusztus 25.) 


\section{Digitális dokumentumtárak (NymETudástár, ${ }^{18}$ Intranet, Google szolgál- tatások $^{19}$ )}

Az oktatók e-tananyagai, az oktatási céllal digitalizált kötelező irodalmak, az intézménnyel kapcsolatos dokumentumok szükségessé teszik digitális dokumentumtárak használatát. A SEK Könyvtára intraneten már 2003-tól müködtet a szerzői jogszabályoknak megfelelő DRM szolgáltatáson alapuló e-dokumentumtárat. Az intézményi IP-címtartományból elérhető oktatói jegyzetek, diplomadolgozatok, tanítási segédanyagok csak olvasásra jeleníthetők meg a képernyőn. 2010-től az egyetemi könyvtári rendszerben pályázati támogatásból létrejött a NymE Tudástár dokumentumtár. Célja az egyetemen keletkezett e-dokumentumok egységes, viszszakereshető, DRM-mel szabályozható, dokumentumtípustól független, interneten bárhol elérhető digitális szolgáltatása elsősorban az egyetem polgárai számára.

Egy felsőoktatási könyvtárban ma már alapszolgáltatásnak kell tekinteni a digitális dokumentumtár(ak) müködtetését, de ami még fontosabb, hogy ezt meg kell ismertetni és használtatni is kell az oktatókkal, és be kell építeni a digitális tanulás folyamatába.

\section{8 . Magyar Tudományos Múvek Tára (MTMT) ${ }^{20}$}

A tudományos publikációk bibliográfiai adatainak gyüjtésére szánt Magyar Tudományos Mủvek Tára adatbázis használata során kiderült, hogy a szerzők többségének nincs gyakorlata szabványokon alapuló metaadatbázisok építésében. Az egyes intézményekben az MTMT adminisztrátori tevékenységével eleve könyvtárosokat bíztak meg, akik az ellenőrzési folyamatok során inkább maguk viszik be a publikációkat az adatbázisba. Az utólagos javítások, adatkeresések sokszor több időt vesznek igénybe, ezért kapacitástól függően a könyvtárosok vállalják el az adatbevitelt is. A helyismereti gyüjteményben tárolt publikációkat önkéntesek digitalizálják, majd az MTMT adminisztrátorok csatolják az egyetemi repozitóriumban lévő rekordhoz.

\section{Összegzés}

A Savaria Egyetemi Központ Könyvtára minden szolgáltatására igaz, hogy a leterhelt oktatói és hallgatói felhasználói kör részére minél egyszerübb és automatizáltabb megoldásokat igyekszik nyújtani. A könyvtárosoknak folyamatosan bővíteniük kell kompetenciáikat nemcsak informatikai, hanem oktatási területeken is. Szükséges az oktatók, hallgatók és minden könyvtárhasználó számára direkt, személyre szabott képzések biztosítása, azonnali „ügyfélkapcsolati szintü” szolgáltatások bevezetése. A SEK Könyvtára a bemutatott tanulástámogató szol-

\footnotetext{
${ }^{18} \mathrm{http}: / /$ tudastar.nyme.hu (2016. augusztus 25.)

${ }^{19} \mathrm{https}$ ://www.google.hu/intl/hu/about/products (2016. augusztus 25.)

${ }^{20} \mathrm{https}: / /$ www.mtmt.hu (2016. augusztus 25.)
} 
gáltatások alkalmazásán keresztül kívánja - megfelelve a 21. század elvárásainak - direkt módon közvetíteni azokat a tartalmakat, amelyekre az oktató, kutató munka során használóinak szüksége lehet.

\section{Rezümé}

Az előadás összefoglalóan bemutatja azokat a digitális szolgáltatási eszközöket, formákat, amelyeket a NymE Savaria Egyetemi Központ Könyvtára alkalmaz a megváltozott tanulási környezetben. A hagyományos könyvtári ellátás mellett a könyvtár bekapcsolódik az intézmény e-learning adminisztrátori feladataiba, továbbképzi az oktatókat és hallgatókat, módszertani segítséget nyújt az elektronikus tananyagok elkészítéséhez. Podcast eszközrendszer használatával törekszik az 1980-as évek ,,szombathelyi modell”jének felújítására. Eszközökkel, módszertani és szerkesztési támogatással segíti az oktatókat az oktatás digitális világának kialakítására, valamint plágiumkereső szolgáltatással támogatja munkájukat. A hallgatók jogszabályok szerinti dokumentumellátását elektronikus dokumentumtárakkal biztosítja.

\section{Teaching and Learning Support Services in Savaria Campus Library}

My paper presents the digitaltools and services that Savaria Campus Library, University of West Hungary provides for the users in the constantly changing learning environment. Besides the traditional library services our library is engaged in e-learning, provides training for the teachers and the students, and also provides methodological support for preparing e-learning materials. Applying podcast technology our library wants to revive the so-called "Szombathely model", which was an educational methodology in the 1980s based on state-of-the-art technology. Our library supports educators in shaping the digital educational and research environment by providing tools, technology and methodology. We also help teachers in originality checking to fight plagiarism by providing Ephorus (Turnitin) service. We also support the learning and teaching activities by building an electronic document repository.

CSUK CSABA

könyvtárigazgató-helyettes

Nyugat-magyarországi Egyetem Savaria Egyetemi Központ Könyvtár és Levéltár 